\title{
MORPHOLOGY AND STRUCTURE OF BRIGHT ELECTRODEPOSITED METAL COATINGS*
}

\author{
Miomir G. Pavlović*, Ljubica J. Pavlović \\ University of Belgrade, ICTM-Department of Electrochemistry, \\ Njegoševa 12, 11000 Belgrade, Serbia \\ duki@tmf.bg.ac.rs
}

\begin{abstract}
The properties which determine whether the metal surface is mirror bright are precisely determined by scanning electron microscopy (SEM), atomic forces microscopy (AFM), scanning tunneling microscopy (STM) and reflectance spectrophotometry investigations. Mirror brightness of metal surfaces can be associated with the high degree of mirror reflection which approaches very nearly the ideal reflectance of the same metal with the lowest degree of diffuse reflection. Mirror brightness of the copper coatings and the copper surfaces polished both mechanically and electrochemically was determined by flat and mutually parallel parts of the surface, which are smooth on the atomic level and which point out towards layer structure of these surfaces. Mirror bright metal surfaces can be obtained only by electrochemical polishing or electrochemical deposition in the presence of brightening addition agents.
\end{abstract}

Key words: bright coatings; electrodeposition; structure; SEM; STM and AFM techniques

\section{МОРФОЛОГИЈА И СТРУКТУРА НА СЈАЈНИ МЕТАЛНИ ПРЕМАЗИ ДОБИЕНИ СО ЕЛЕКТРОДЕПОЗИЦИЈА}

Својствата кои определуваат дали металната површина ќе има метален сјај се прецизно одередени со помош на SEM, AFM, STM и рефлексиона спектрофотометрија. Огледалниот сјај на металните површини може да се поврзе со висок степен на рефлексија, кој се приближува речиси до идеална рефлективност на истиот метал со најмал степен на дифузна рефлексија. Огледално сјајната површина на бакарни премази и на бакарни површини полирани механички и електрохемиски беше утврдена преку рамни и заемно пралелни делови од површината кои се мазни на атомско ниво, насочени кон слоевита структура на овие површини. Огледално сјајни површини можат да се добијат само со електрохемиско полирање или електрохемиска депозиција во присуство на адитиви за сјајност.

Клучни зборови: сјајни премази; електродепозиција; структура; техники SEM, STM и AFM

\footnotetext{
* Dedicated to Professor Svetomir Hadži Jordanov on the occasion of his $70^{\text {th }}$ birthday.
} 


\section{INTRODUCTION}

One of the basic theoretical issues in electroplating technology is linked to obtaining bright metal coatings. Brightness of the metal surfaces has no quantitative evidence, so the mirror reflection of a parallel beam of visible light from the surface of the polished metals is taken as the measure of the degree of brightness $[1,2]$. In other words, the coating that has better coating reflectance is brighter. Mirror reflection (specular reflection) means that the reflected light has the angle equal to the incoming light angle on the surface. The opposite case of mirror reflection is a diffuse reflection, where the incident beam is scattered in all possible directions.

Although the bright coatings are obtained in practice without major problems, the mechanism of their formation is still unknown. Besides, it is still unknown which conditions should be fulfilled in order to obtain mirror bright metal coating. It seems that this last question is easily resolved by examining and comparing the reflected light from variously prepared and variously polished surfaces.

It should be noted that the mirror brightness is not affected by wavy or microroughness of the metal surfaces which can be seen with the naked eye or under microscope. In general, microroughness of the metals can be reduced to the extent of about ten micrometers without jeopardizing their apparent brightness.

From the above, it follows that it is useful to divide metal surface roughness in two groups when studying the formation of their bright surfaces:

a) microroughness and

b) submicron roughness.

Third group can be named - the roughness visible to the naked eye. Yet the latter has little influence on the surface brightness.

Microroughness includes protrusions and valleys on the surface of metals in order of several to hundred micrometers. Submicron roughness includes bulges, peaks and valleys with dimensions not exceeding $1 \mu \mathrm{m}$.
When the metal surface which will be covered is carefully polished, then the first layer of every metal is deposited as bright coating, because there is no submicron roughness. However, with increase of the coating thickness, from the regular baths without the brighteners, their crystal structure quickly grows larger and the surface gets a dull or mat appearance. This is due to the fact that during the deposition of metal from the basic salts, without appropriate additives, the rate of nuclei formation is significantly lower than the speed of their growth [3]. This means that during prolonged electrolysis, separated crystallites of deposited metals are gradually increasing, form aggregates, and the roughness of the deposited surface increases and diminishes their brightness. In other words, from the solution of basic salts during prolonged electrodeposition it is not possible to obtain bright metal coating.

When the alignment of the surface, i.e. filling of the submicron bulges and valleys, happens during deposition of bright metal coatings, then we can talk about the leveling effects of the electrolyte. However, the above-mentioned features of the bright metal surfaces show that there is no principled difference between the process of creating bright coatings and their leveling. Brightening and leveling are closely related, although many solutions capable of producing bright deposits have no leveling ability. Leveling is practically important; use of leveling solutions may eliminate the requirement for buffing the substrate [4]. Creating brightness is also the process of leveling. In this case, the submicron surface irregularities, that are not visible under the optical microscope, are smoothened.

In practical galvanotechnique, metallic products that are finely polished and perfectly bright are rarely covered. More common case is to obtain a bright and smooth surface on fine-polished but microrough, dull surfaces. On such objects, when introduced in the galvanic bath, even the first-thinnest electrodeposited layers of metals have large microstructure and mat appearance. In this case, in order 
to obtain the mirror bright deposits, it is necessary to accelerate not only the formation of crystallization centers, but also to enable easily formation of the nucleus in microvalleys rather than on microprotrusions of the area to be covered. This is achieved by use of surface-active substances, called brighteners. Baths without addition agents seldom or never produce bright deposits; the addition agents, usually organic compounds, which act to turn a dull or mat deposit into a bright one [4].

The first necessary condition for every brightener is its adsorption on the surface of freshly deposited metal. However, it is still insufficient for the development of the bright galvanic coatings. Roth and Leidheiser [5] have found in 1953 that the ability to create bright surfaces have only those additives that cause the increase of cathode potential for the deposition of about $20-50 \mathrm{mV}$. On this basis, they concluded that for the formation of bright deposits it is necessary that adsorption film of the additive covers only a part of the cathode surface. Specific measurements of cathode potential, impedance, rate of consumption of brightener and rate of its incorporation in the coating, it is often possible to evaluate semi-quantitatively the rate of its adsorption and the degree of covering of cathode surface with its molecules, at any time of electrolysis. For instance, using these methods it was found that thiourea causes the mirror brightness of the copper coatings when its adsorbed molecules cover $50-90 \%$ of the visible surface of the cathode $[1,6]$. Also it was found that polyethyleneglycols induce the mirror brightness of copper deposits when their concentration in the electrolyte, for a given current density, provide 32-91\% coverage of the visible surface of the cathode with their adsorbed film [1, 6-8].

Generally, brighteners must have the following features [8]:

- they must be adsorbed on the cathode, they must cause an increase in overpotential for discharging metal ions to be deposited, and they must extremely enlarge the formation of small-grain coatings;
- they must cover only part of the cathode surface that is constantly renewed and they must form stationary, non-compact film or film formed from the island;

- additive molecules, which form noncompact adsorption film, must be constantly rearranged on the cathode surface and they must create the conditions for constant leveling of its microrelief.

Regardless of all the forth, one may say that almost all the knowledge about the bright coatings is either at the level of empirical facts, or at the level of not enough substantiated theories, so this area provides great opportunities for further research. For example, only with the development of AFM and STM techniques the possibility of experimental testing of assumptions about the surface topography, roughness or coarseness, which determines whether a coating of metal is bright or not, and the effect of thick bright coating on its roughness is opened [9-11]. It is especially important that AFM and STM offer the possibility for quantifying surface roughness on the submicron level. Application of STM and AFM techniques proved to be very useful for examining the topography of deposits obtained by electrolysis. Using different STM and AFM software, the analysis of the surface profile (linear analysis) and part of the surface (surface analysis) is possible. The advantage of these techniques is in high resolution which they achieve; for example: each part of the surface profile or any part of the surface can be described by the function that is defined in relation to a flat surface placed below the lowest part of the test surface.

In order to determine the structural characteristics of metal coatings that must be fulfilled so that they mirror reflected light structure was tested mechanically, and mechanically then electrochemically polished surfaces of copper, and copper metal coatings deposited with the appropriate brightener. In addition, the aim was to determine how the deposition time and thickness of the coating affects its texture and microstructure. Structure of metal sur- 
faces were investigated by scanning tunneling microscopy (STM), atomic forces microscopy (AFM), scanning electron microscopy (SEM) and measuring the reflected light from their surfaces.

\section{PHENOMENON OF LEVELING OF METAL COATINGS}

It is known that the addition of small amounts of certain substances in plating baths leads to significant changes in properties of deposits obtained on the cathode. Some of these substances have the ability to level the surface of the electrode. Often, these are organic substances, which are known as leveling agents or leveling additives in the literature.

By leveling it is considered throwing power of galvanic baths to produce relatively thick deposits in the valleys (holes) and thin deposits on the peaks (protrusions) of the electrodes, with the ultimate effect of reducing the initial roughness of the electrode surface $[4,12]$. It is necessary to distinguish the difference between "geometric leveling", which is the result of a uniform current density distribution, and leveling in the presence of organic substances, which is the result of higher current density in the holes, than on the peaks of the microprofile [13]. The latter is usually called "true leveling", where the deposit is thicker in the valleys than on the peaks, and the plated article is smoother than the original work [4].

Previous experimental results generally indicate that the process of leveling takes place under conditions of complete (total) diffusion control of the adsorption or discharging of the leveling agent [14].

It can be assumed that in the case of diffusion controlled leveling, leveling agent diffuses from the solution and adsorbs primarily on the tops of peaks and less in the valleys of the electrode. This leads to metal adatoms migration to the valleys on the electrode, where they are finding a suitable place for incorporation in the crystal lattice [15].
Higher adsorption of the leveling agents on the top of the surface irregularities leads to local reduction in current density of deposition compared to less exposed parts of the surface. Hence, leveling is directly related to the difference in surface concentration of the leveling agent, which causes the differences in local current densities.

In order for proposed model to be satisfied, two conditions have to be fulfilled:

a) the maximum height of the protrusion on the surface, $h$, should be considerably smaller than the thickness of diffusion layer, $\delta$, so that the condition $\delta>>h$ is fulfilled, and

b) the leveling agent must be, somehow, used on the electrode, most probably through the electrochemical reaction at the cathode, or through incorporation into the crystal lattice of the coating.

Leveling effect can be described by the same mechanism as amplification of surface irregularities under conditions of complete diffusion control process of deposition [14].

Quantitative interpretation of this mechanism is given in [16].

Physical model of a situation where a reduction in roughness occurs is shown in Figure 1, which is simplified scheme of the current distribution on the cathodes surface microrelief under conditions of complete diffusion control.

The assumptions are that the leveling agent adsorbs or electrochemically reacts on the cathode, that $\delta>>h$, and that deposition process is under complete diffusion control, so the current density depends solely on the local thickness of diffusion layer at each point of the electrode surface.

The current density in the absence of leveling additive should be marked as $j$. In the presence of parallel reaction of reduction of additive it will be reduced and the value will be:

$$
j_{1}=j-\frac{n_{2} D F C_{0}^{*}}{\delta-h}
$$




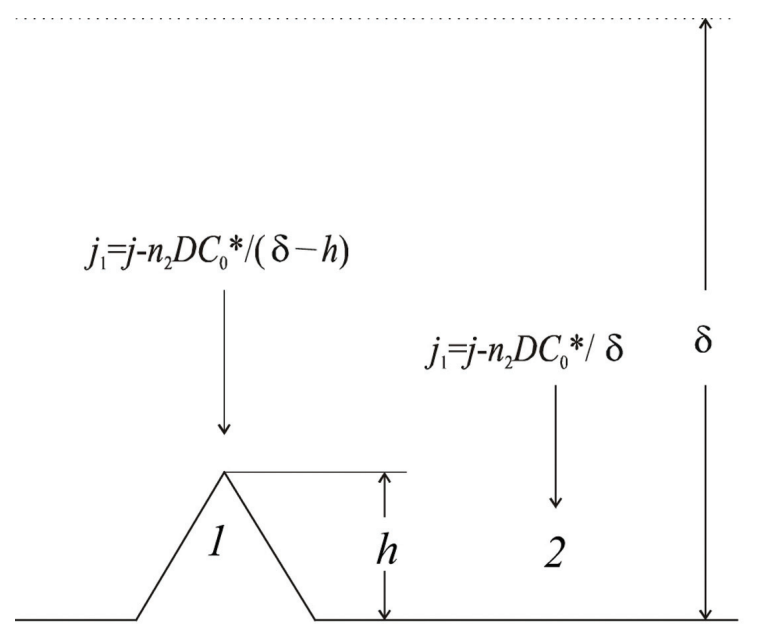

Fig. 1. Simplified physical scheme of the current density distribution on the relief of the electrode surface under conditions of complete diffusion control $(h$ - height of protrusion relative to the plane of the electrode surface) [16].

i.e.

$$
j_{2}=j-\frac{n_{2} D F C_{0}^{*}}{\delta}
$$

in the points 1 and 2 on the electrode surface, as illustrated in Figure 1. Point 1 in Figure 1 simulates the top of protrusion on the surface and point 2 illustrates valley on the electrode surface. In the equations (1) and (2) $n_{2}$ represents the number of exchanged electrons for the process of additive discharge, $C_{0}^{*}$ represents the concentration of the additive in the bath, $F$ is Faraday constant and $D$, the diffusion coefficient.

The difference in rates of growth of metal layers at points 1 and 2 can be expressed by the following equation:

$$
\frac{\mathrm{d} h}{\mathrm{~d} t}=\left(\frac{\mathrm{d} d}{\mathrm{~d} t}\right)_{1}-\left(\frac{\mathrm{d} d}{\mathrm{~d} t}\right)_{2}
$$

Starting from Faraday's law, it can be easily shown that [16]:

$$
\frac{\mathrm{d} d}{\mathrm{~d} t}=\frac{V}{n_{1} F} j
$$

where $V$ is the molar volume of metal, and $n_{1}$ the number of exchanged electrons for process of metal deposition.

After taking $j_{1}$ and $j_{2}$ from the Eq. 1 and Eq. 2 and putting into Eq 3 and Eq. 4, the following expression is obtained:

$$
\frac{\mathrm{d} h}{\mathrm{~d} t}=V D \frac{n_{2}}{n_{1}} C_{0}^{*}\left(\frac{1}{\delta}-\frac{1}{\delta-h}\right)
$$

For $\delta>>h$ by integrating Eq. 5 it is obtained

$$
h=h_{0} \exp \left(-\begin{array}{l}
t \\
\tau
\end{array}\right)
$$

where $h_{0}$ is the initial height of the peaks and $\tau$ is time constant given by Eq. 7

$$
\tau=\frac{n_{1}}{n_{2}} \frac{\delta^{2}}{V D C_{0}^{*}}
$$

From Eq. 6 it follows that increase of the deposition time reduces the height of the protrusion, i.e. the leveling of the electrode surface occurs.

Former consideration is extremely simplified, but it well reflects the physical essence of the process.

If the leveling additive electrochemically reacts on the electrode surface and it comes by diffusion from the mass of the electrolyte, a part of the current density, which accounts for discharging additive, is higher at the top of the protrusion than on the flat part of the surface. Therefore, the portion of the current density, $j_{1}$ and $j_{2}$ which reduces metal ions will be lower at the top of the peak than on a flat part of the surface, which leads to leveling of the surface during prolonged deposition time [14, 17]. It is often necessary to add brightener besides leveling additive. According to Nichols et al. 
$[18,19]$ it is most likely that adsorbed active additive blocks growth in the vertical direction. By adsorption of additives on flat surface, additive directs deposition of metal on the steps of growth, which leads to the formation of atomic smooth layered coating. Smooth and bright galvanic coatings are obviously formed by synergetic action of these two types of additives, where additive for leveling have influence on the micro-level in the vertical direction, and additives for growth blocking have influence in the vertical direction on the nano-level.

\section{EXPERIMENTAL}

Rolled copper plates of purity $99.9 \%$ and dimensions $(5 \times 5 \times 0.05) \mathrm{cm}$ were polished in two ways: mechanically and mechanically then electrochemically. The surface of the sample was mechanically polished with silicon carbide emery paper grade: 320,500 and 1.000 , and then with aluminum oxide powders ( 1.0 and 0.3 $\mu \mathrm{m})$. The electrode was held in a Teflon holder which was exposed only to the surface which was polished. Some of electrodes were further polished electrochemically following a procedure which enabled mirror reflection degree of $90 \%$ to be reached, whereas reflection from the metal surface polished only mechanically amounted to $70-75 \%[1,2,10,20]$. Deposition was carried out from two baths; with basic solution composition: $240 \mathrm{~g} / \mathrm{L} \mathrm{CuSO}_{4} \cdot 5 \mathrm{H}_{2} \mathrm{O}+$ $60 \mathrm{~g} / \mathrm{L} \mathrm{H}_{2} \mathrm{SO}_{4}$ and from basic solution with the brightener thiourea $(\mathrm{AB})$, at temperature of $25^{\circ} \mathrm{C}$. Current density of deposition was $1 \mathrm{~A} / \mathrm{dm}^{2}$.

Electrolyte with composition $74 \%$ $\mathrm{H}_{3} \mathrm{PO}_{4}+6 \% \mathrm{CrO}_{3}+20 \% \mathrm{H}_{2} \mathrm{O}$ was used for electrochemical polishing, at current density of $40 \mathrm{~A} / \mathrm{dm}^{2}$, temperature $30{ }^{\circ} \mathrm{C}$ and the polishing time ranged from 1 to $3 \mathrm{~min}$. The measurements were made in an open electrolytic cell $\left(200 \mathrm{~cm}^{3}\right)$ with a counter electrode of electrolytic copper (99.99\%).

Mirror reflection of visible light was determined using a Reflectance Spectrophotom- eter BECKMAN UV 5240, i.e., the specimen was illuminated by a beam whose axis was at an angle not exceeding $10^{\circ}$ from the normal to the specimen [normal/total (abbreviation, 0/t): normal/diffuse (abbreviation, $0 / \mathrm{d}$ )]. The reflected flux was collected by means of an integrating sphere [10]. The difference of two curves (total - diffuse) gives the mirror reflection, which is a parameter for surface brightness.

The morphology of the surface was examined by scanning electron microscopy (SEM) type JOEL T20.

The topography of the surface was determined by AFM and STM, type "NanoScope III" in air ("Digital Instruments"). The images were obtained in the constant current mode using a $\mathrm{W}$ tip electrochemically sharper in $1 \mathrm{M}$ $\mathrm{KOH}$ solutions. Bias voltages ranging from 8.9 to $18.1 \mathrm{mV}$ and tip currents from 3.0 to $4.9 \mathrm{nA}$ were used.

The AFM and STM images were taken immediately after only mechanical or both mechanical and electrochemical polishing in a short time interval (less than $10 \mathrm{~min}$ ) which ensures the $\mathrm{Cu}$ surfaces remains free of oxides.

\section{RESULTS AND DISCUSSION}

Figure 2 shows the copper polarization curves from sulfate solutions with and without the brightener. According to Matulis [1, 8], bright coatings should be obtained in the cur-

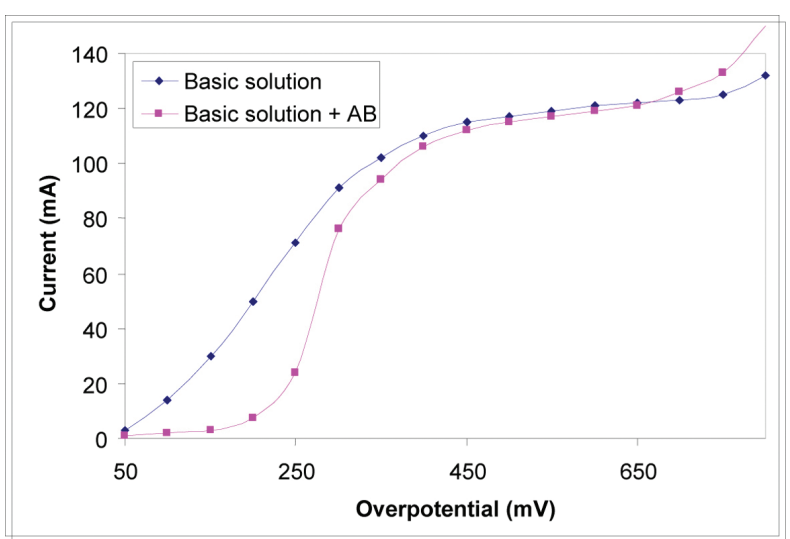

Fig. 2. Polarization curves for copper deposition with and without the brightener. Basic solution: $240 \mathrm{~g} / \mathrm{L} \mathrm{CuSO}_{4} \cdot 5 \mathrm{H}_{2} \mathrm{O}+60 \mathrm{~g} / \mathrm{L} \mathrm{H}_{2} \mathrm{SO}_{4}$. Brightener thiourea. Surface area of the working electrode $1 \mathrm{~cm}^{2}$, electrolyte temperature $25^{\circ} \mathrm{C}$. 
rent density region of $20-90 \mathrm{~mA} / \mathrm{cm}^{2}$, because in that region the overpotential difference with or without brighteners is $50-20 \mathrm{mV}$. The experiments were performed at cathodic overpotential of $250 \mathrm{mV}$ which is in the region for obtaining bright coatings in the presence of additive.

Figure 3 shows the SEM microphotograph of initial surface of mechanically polished copper (cold rolled $\mathrm{Cu}$ sheet), and in Figure 4 shows SEM microphotograph of the same sample of copper but electrochemically polished.

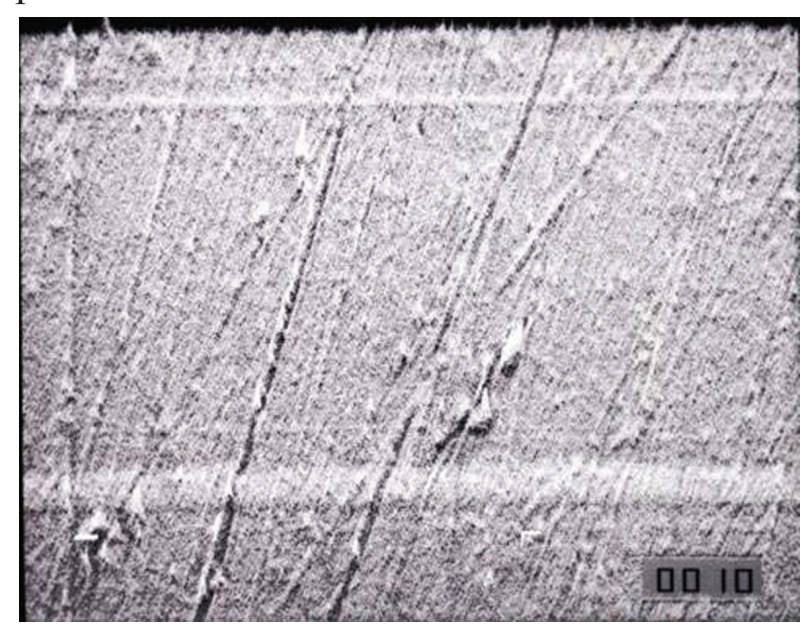

Fig. 3. SEM microphotograph of mechanically polished $\mathrm{Cu}$ substrate surface (topography). ${ }^{\times} 750$

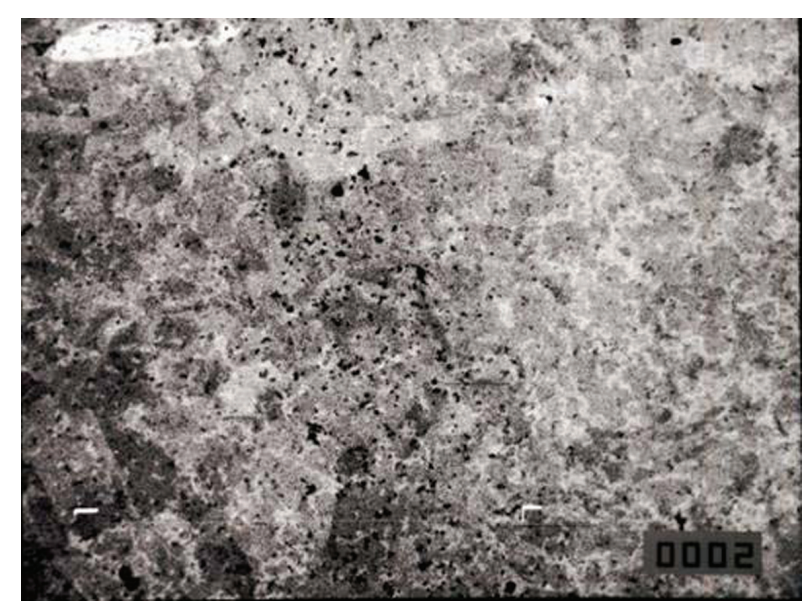

Fig. 4. SEM microphotograph of mechanically then electrochemically polished $\mathrm{Cu} .{ }^{\times} 750$

Analyzing Figure 4, it was concluded that even with a high brightness copper surface, some "inclusions" are noticeable in it. Therefore, the X-ray diffractogram of electrochemically polished copper specimen was done (Figure 5). However, structural Röntgen analysis showed only the presence of f.c.c. lattice of copper, with space group Fm $3 m$. Only reflections from $\{111\}$ and $\{200\}$ of copper planes are observed and there is absence of other phases. Measurements were performed in the range of $40-70^{\circ}$, with

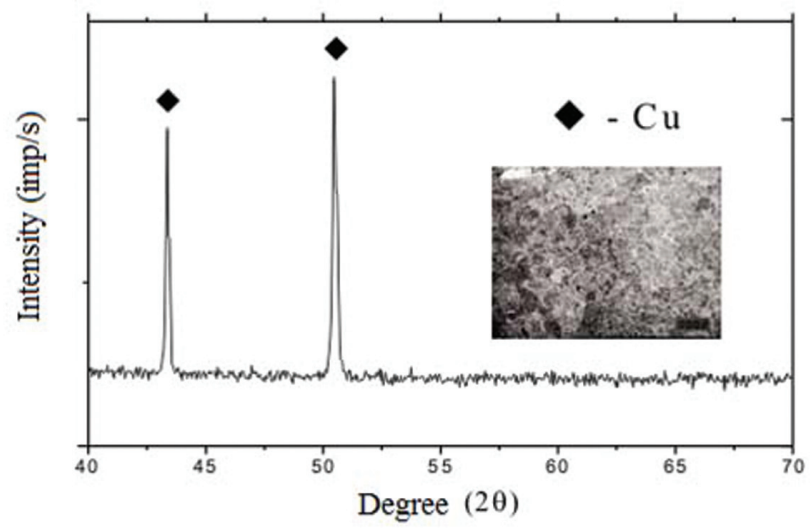

Fig. 5. X-Ray diffractogram of electrochemically polished $\mathrm{Cu}$ sample

continuous scan speed of $0.05^{\circ} 2 \theta / \mathrm{s}$.

The reflection degree as a function of light wavelengths is shown in Figure 6, for mechanically polished copper plates and ones polished both mechanically and electrochemically, Figure 7; [T-total reflection, D-diffuse component of the total reflection, and S-specular (mirror) reflection]. It is noticeable that the mirror reflection in the latter case is higher by $20-25 \%$.

Optimal time for electrochemical polishing was 3 minutes. When the sample is electrochemically polished only for 1 minute, diffuse reflection increases with respect to the initial sample, while the total reflection remains approximately the same, and the mirror reflection drops by 3-8\%, depending on the wavelength. After electrochemical polishing for 2 minutes, total reflection reaches maximum value for wavelengths higher than $590 \mathrm{~nm}$, while the diffuse component of the overall reflectivity decreases and the specular reflectivity increases by $12-15 \%$ compared to the initial sample. After polishing for 3 minutes, diffuse component of the overall reflection decreases in value of about $15 \%$, and mirror reflection increases to values 


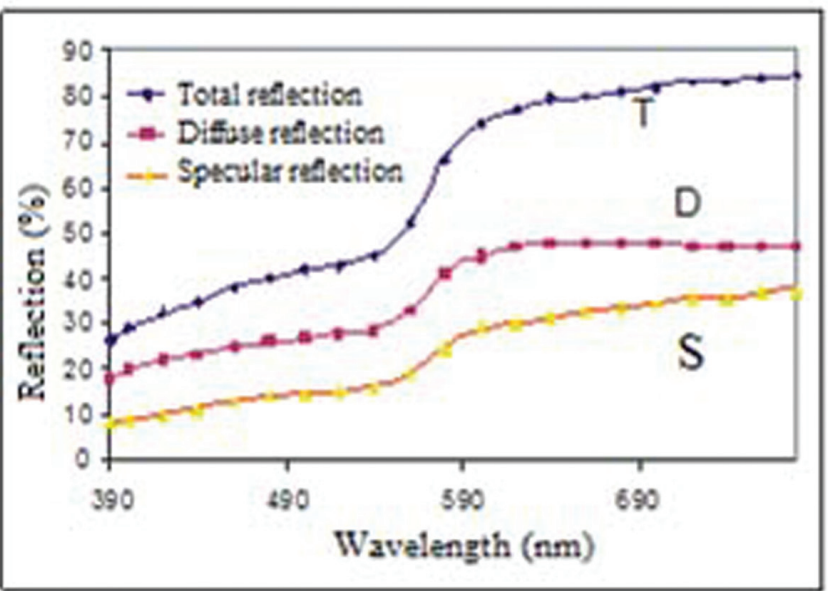

Fig. 6. The dependence of the reflection degree of the light wavelength for mechanically polished $\mathrm{Cu}$ plates.

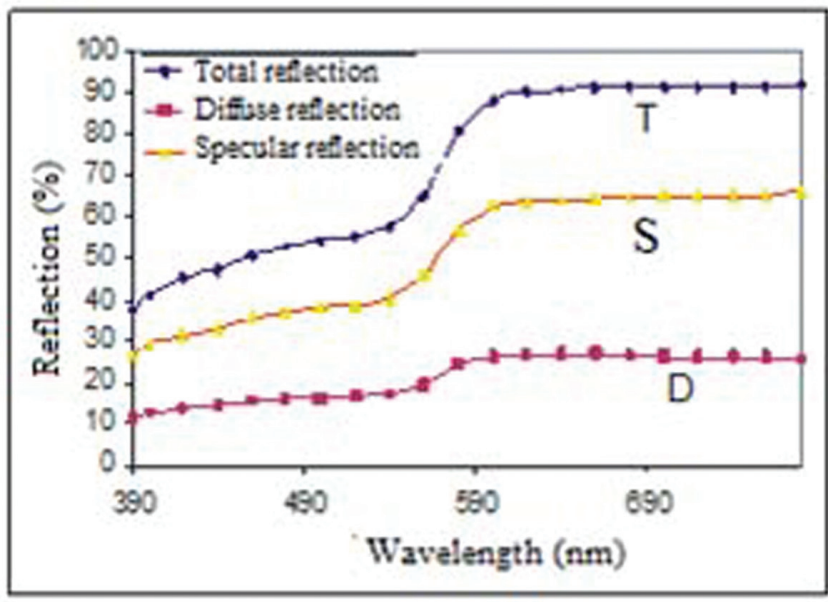

Fig. 7. The dependence of the reflection degree of the light wavelength for electrochemically polished $\mathrm{Cu}$ plates. Time of polishing 3 minutes

of about $65 \%$ (at wavelengths above $600 \mathrm{~nm}$ ), under the total reflection of $90 \%$. When copper surface is electrochemically polished longer than 3 minutes, pitting occurs on it, surface loses its brightness and it becomes useless for measuring reflected light.

Following the change in specular, total and diffuse reflection it can be seen that there has been a significant increase in the brightness with electrochemically polished surfaces (Figures 4 and 7), compared to initial surface (Figures 3 and 6). In each case, this is related to surface roughness.

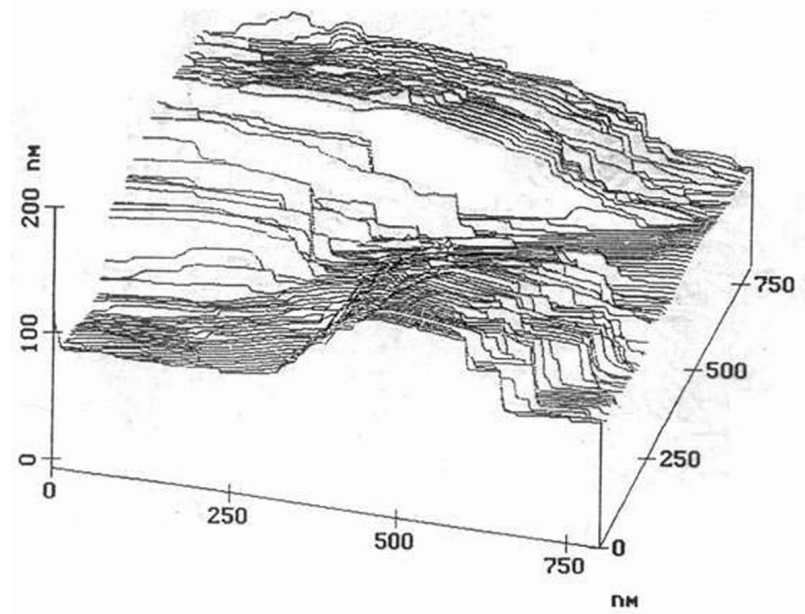

Fig. 8. 3D STM image $(880 \times 880) \mathrm{nm}^{2}$ of the mechanically polished copper surface [10].

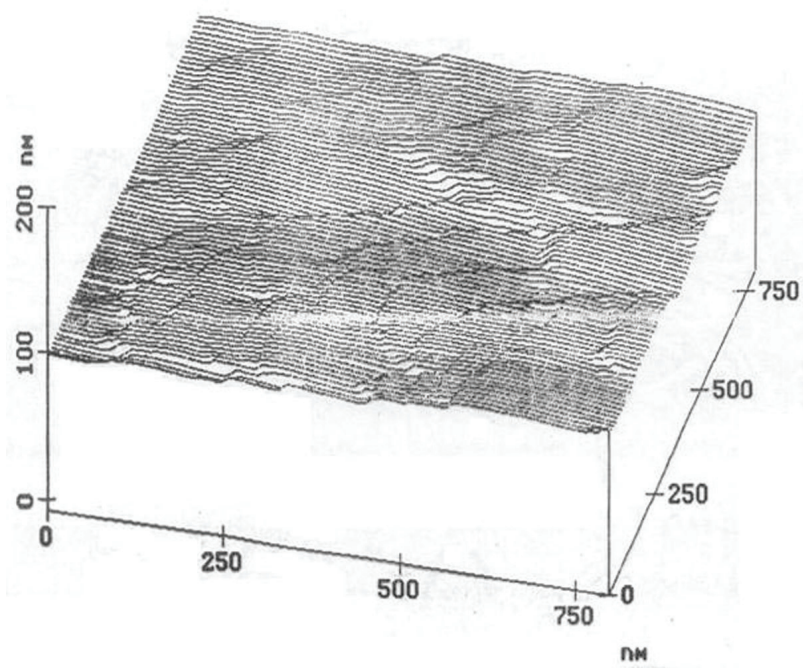

Fig. 9. 3D STM image $(880 \times 880) \mathrm{nm}^{2}$ of the mechanically then electrochemically polished copper surface [10].

Figures 8 and 9 show 3D (three dimensional) STM image (scan size $880 \times 880) \mathrm{nm}^{2}$ of mechanically polished copper surface (Figure 8 ) and mechanically than electrochemically polished copper surface (Figure 9). Electrochemical polishing of mechanically polished surface led to a decrease in surface roughness. Also, Figure 9 shows that the structure of copper after electrochemical polishing consists of flat and mutually parallel parts of the surface. Flat parts of the surface are visible at the surface of copper that was mechanically polished, but with a noticeable distance between adjacent parts of the surface (Figure 8). 


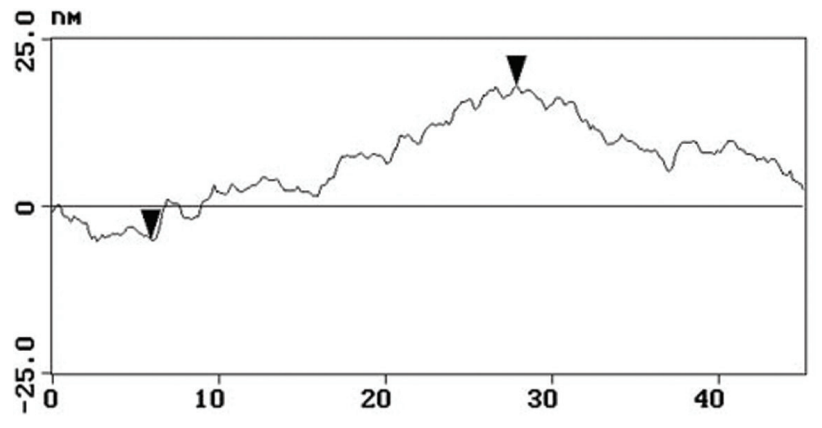

Fig. 10. Typical surface profile of flat parts from a (50 x 50) $\mathrm{nm}^{2}$ STM image (linear analysis) of mechanically polished $\mathrm{Cu}$ surface. The distance between the labels is $17.21 \mathrm{~nm}$.
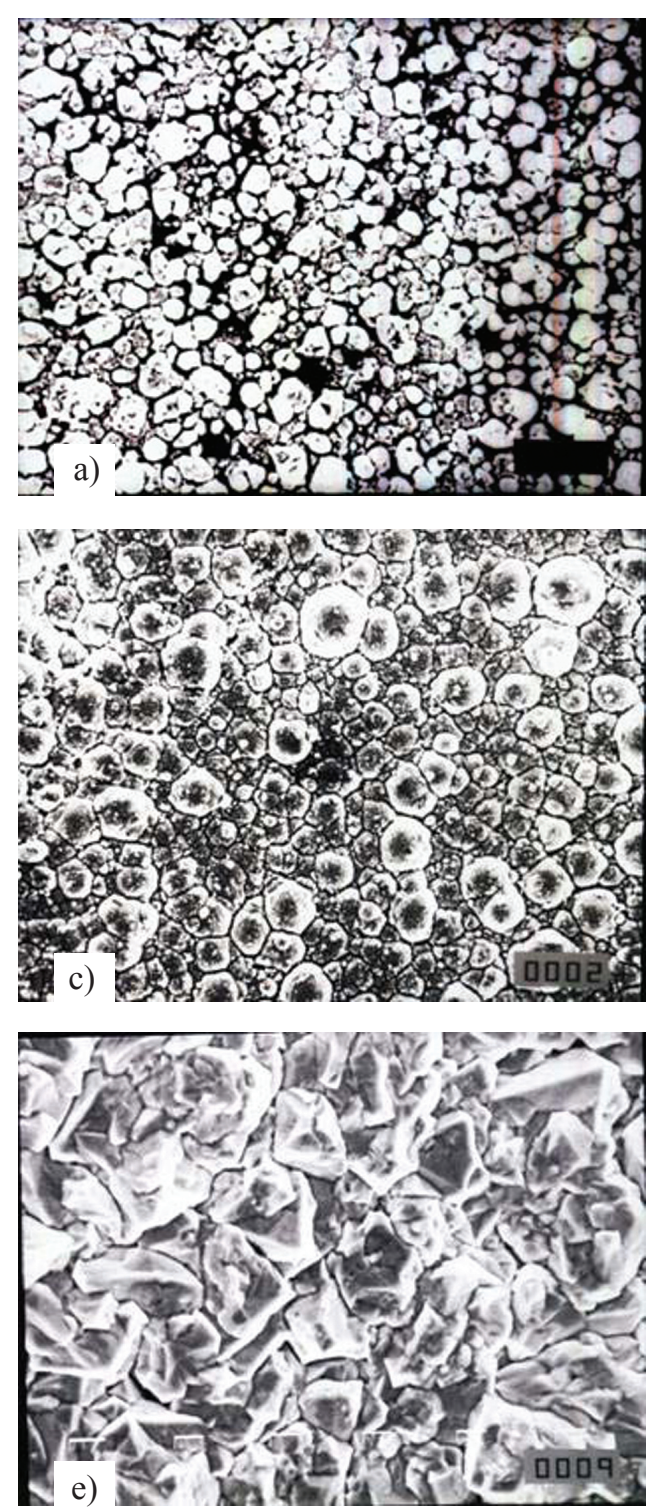

Fig. 12. SEM microphotographs of the $\mathrm{Cu}$ copper coatings obtained from the electrolyte without (a, c and e) and with the brightener (b, d and f). Coating thickness: a) $15 \mu \mathrm{m}$; c) $30 \mu \mathrm{m}$; e) $50 \mu \mathrm{m}$. Magnification $\times 750$; b), d), f): Coating thickness: b) $15 \mu \mathrm{m}$; d) $30 \mu \mathrm{m}$; f) $50 \mu \mathrm{m}$. Magnification $\times 350$.

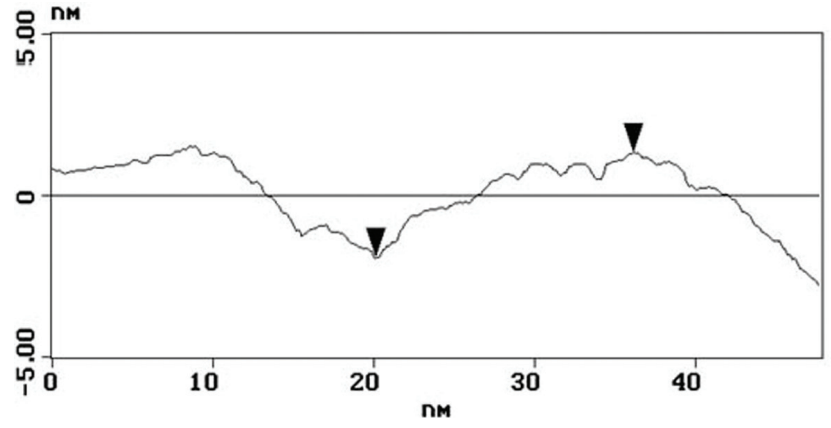

Fig. 11. Typical surface profile of flat parts from a (50 x 50) $\mathrm{nm}^{2}$ STM image (linear analysis) of mechanically then electrochemically polished Cu surface. Distance between the labels is $1.94 \mathrm{~nm}$.
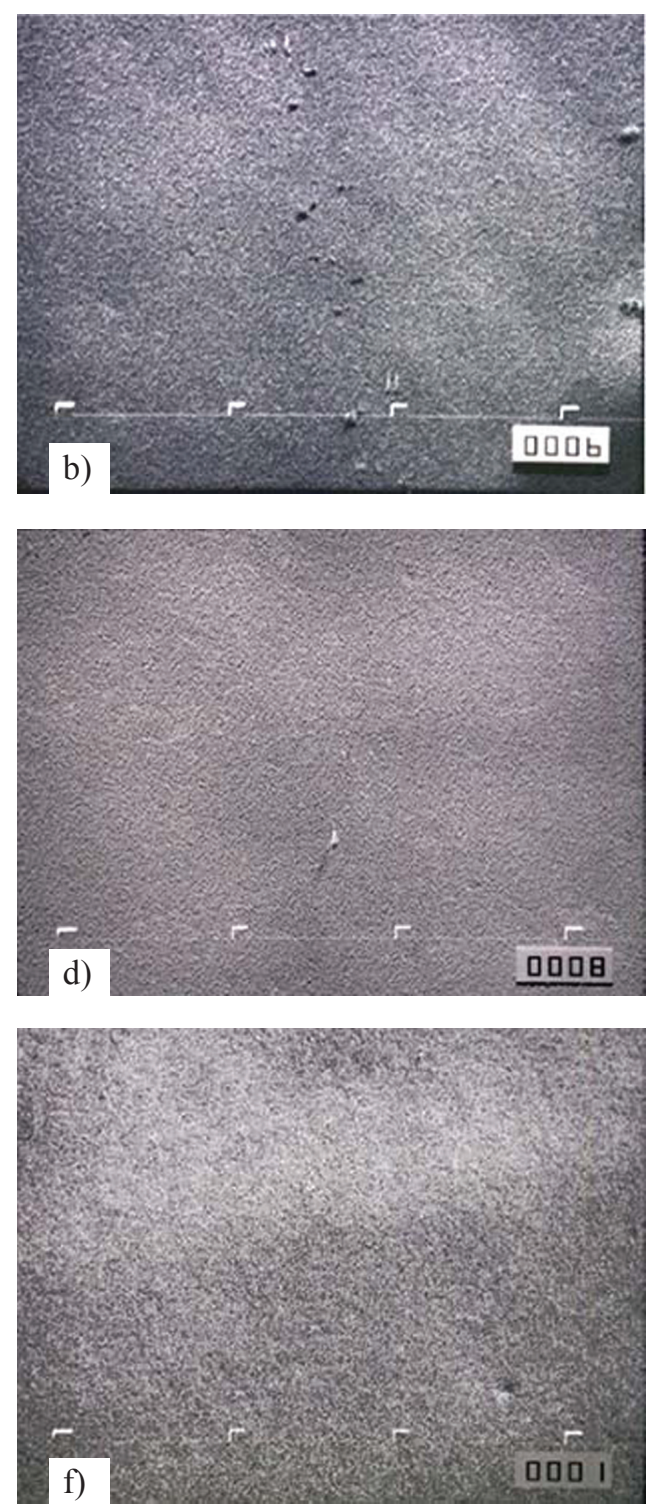
Figures 10 and 11 show $(50 \times 50) \mathrm{nm}^{2}$ linear analysis of mechanically polished copper surface (Figure 10) and mechanically then electrochemically polished copper surface (Figure 11). The distances between adjacent flat parts (marked by the markers on the Figures) are calculated by STM program package. The distance between two labels of flat parts for mechanically polished copper surface is about 70 atomic diameters of copper [1], while the same distance for mechanically then electrochemically polished surface of copper is several atomic diameters of copper. Also, from Figures 10 and 11 it can be seen that these relatively flat parts

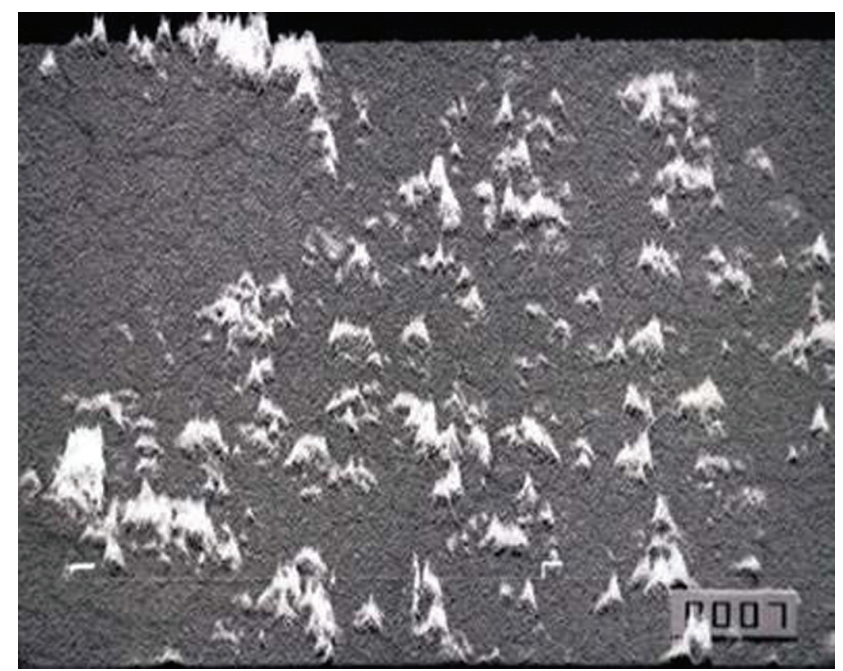

Fig. 13. SEM microphotograph (topography) of the mat galvanic $\mathrm{Cu}$ coating surface; coating thickness 15 $\mu \mathrm{m} .{ }^{\times} 750$.

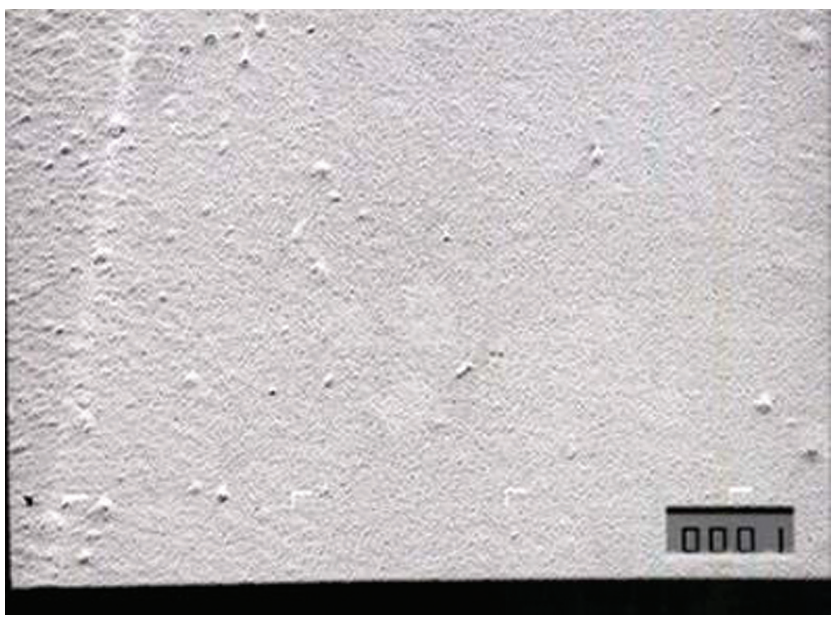

Fig. 15. SEM microphotograph (topography) of bright galvanic $\mathrm{Cu}$ coating surface; coating thickness 15 $\mu \mathrm{m} . \mathrm{X} 750$. of the surface are mutually more parallel with the surface polished both mechanically and electrochemically than the surface polished only mechanically.

STM software measurements showed that the roughness of relatively flat parts of these areas with mechanically then electrochemically polished surface is less than the atomic diameter of copper. The diameter of copper atoms is $0.256 \mathrm{~nm}$, and the roughness of the observed parts is $0.416 \mathrm{~nm}$ for mechanically and 0.122 $\mathrm{nm}$ for mechanically then electrochemically polished sample. So it can be said that these surface planes are smooth at the atomic level.

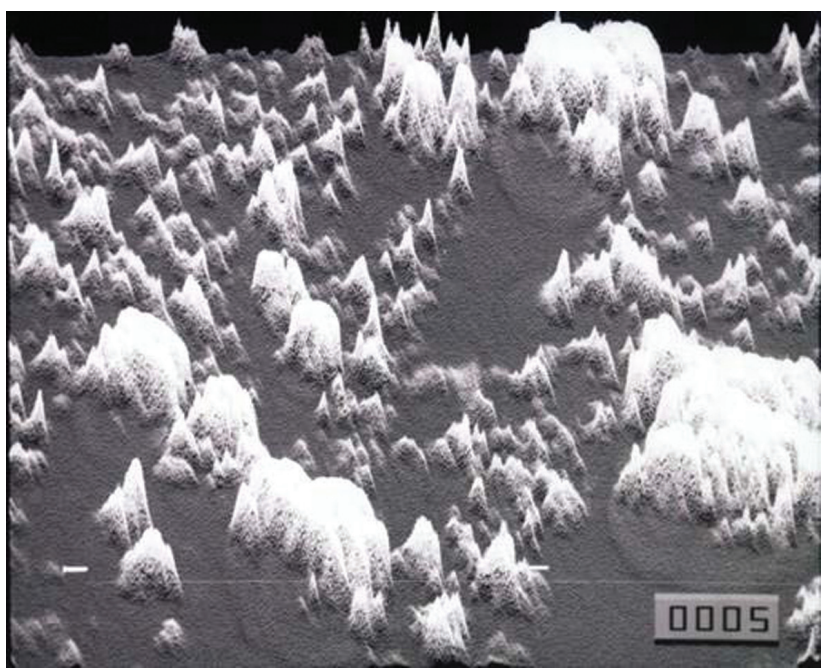

Fig. 14. SEM microphotograph (topography) of the mat galvanic $\mathrm{Cu}$ coating surface; coating thickness 50 $\mu \mathrm{m}$. X750.

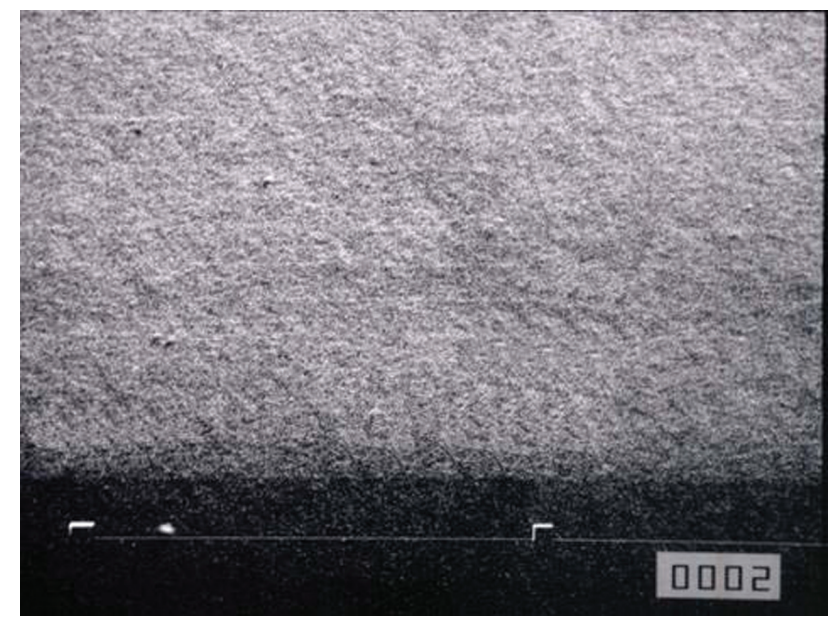

Fig. 16. SEM microphotograph (topography) of bright galvanic $\mathrm{Cu}$ coating surface; coating thickness 50 $\mu \mathrm{m}$. X750. 


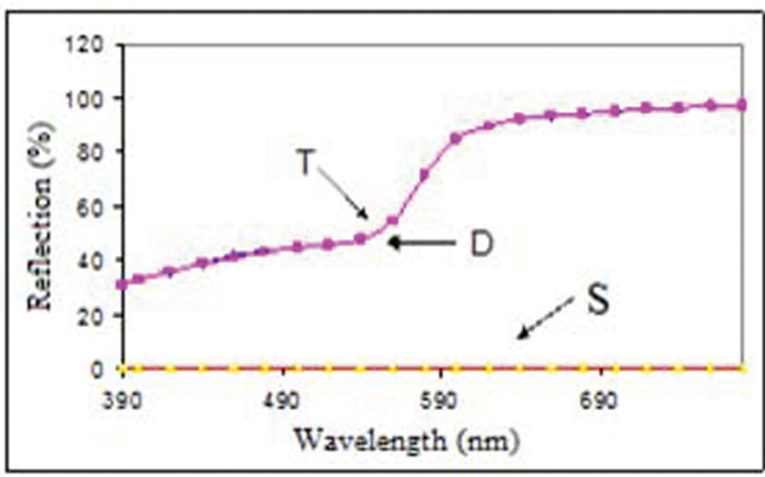

Fig. 17. Mechanically then electrochemically polished sample with mat copper coating; coating thickness $15 \mu \mathrm{m}$

Figure 12 (a-f) shows SEM microphotographs of $\mathrm{Cu}$ metal coatings surfaces obtained from sulfate solution without (a, c and e) and with the brightener (b, $d$ and $f$ ), with thickness of 15,30 and $50 \mu \mathrm{m}$ respectively. There are noticeable differences in morphology of the surfaces for samples obtained with and without the addition agent. With increase in deposition time i.e. with increase in coating thickness, where the electrolyte is without additive, an increase in roughness is present (Figures 13 and 14), while in the presence of additive, copper coating, even with increasing thickness, becomes smoother and smoother (Figures 15 and 16) $[21,22]$.

Figures 13 and 14 show backscattering SEM microphotographs of copper coating surfaces obtained from sulfate solution, without

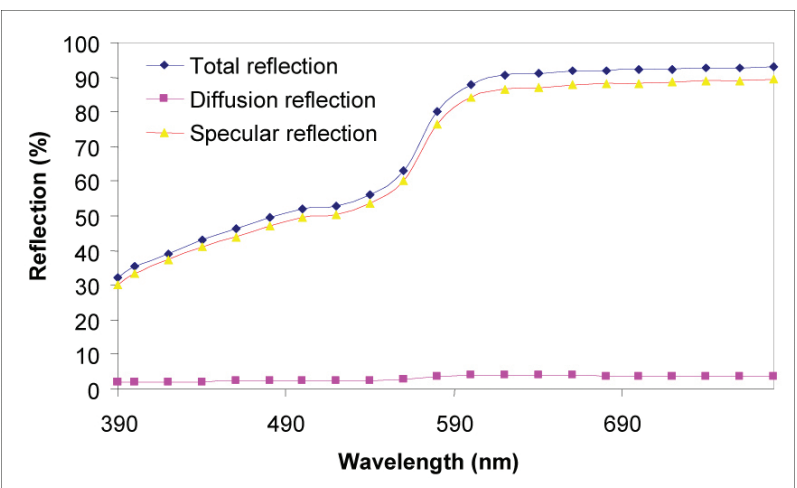

Fig. 19. Reflection vs. visible light wavelength for bright galvanic copper coating; coating thickness $15 \mu \mathrm{m}$.

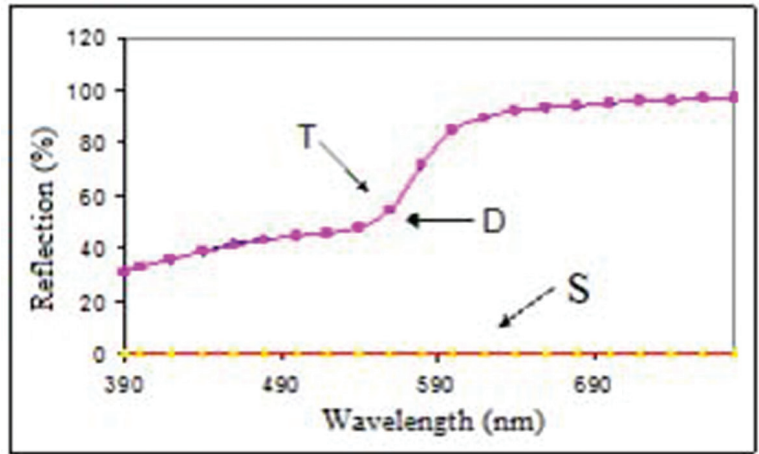

Fig. 18. Mechanically then electrochemically polished sample with mat copper coating; coating thickness $50 \mu \mathrm{m}$

brightener, with thickness of $15 \mu \mathrm{m}$ (Figure 13) and $50 \mu \mathrm{m}$ (Figure 14), respectively. As expected, increase in deposition time and coating thickness, leads to increase in roughness [21, 22].

Figures 15 and 16 show SEM microphotographs of copper coating surfaces, with thickness of $15 \mu \mathrm{m}$ and $50 \mu \mathrm{m}$, obtained from the electrolyte with brightener, respectively. From SEM microphotographs it is obvious that mat coatings have greater roughness than bright coatings, which shows that brightener acts as a leveling agent.

Figures 17 and 18 show the expressed diffusion reflection that occurs on mat surfaces as a result of penetration of light into the sample followed by partial absorption and multiple scattering on the boundaries of numerous grains.

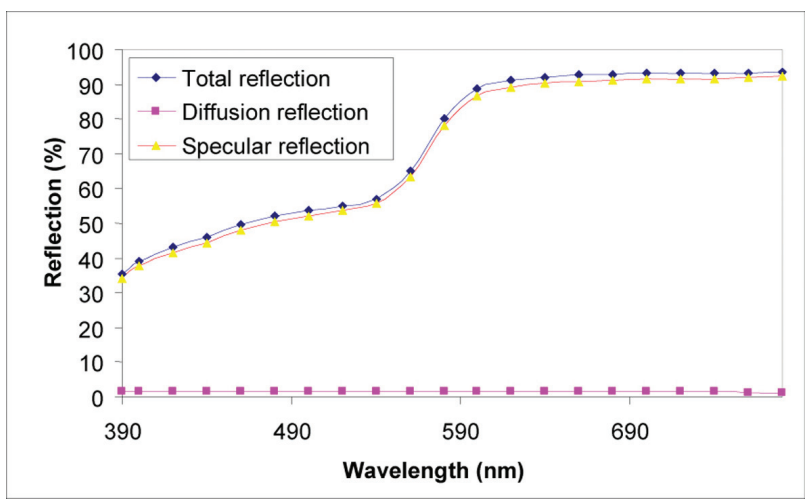

Fig. 20. Reflection vs. visible light wavelength for bright galvanic copper coating; coating thickness $50 \mu \mathrm{m}$ 


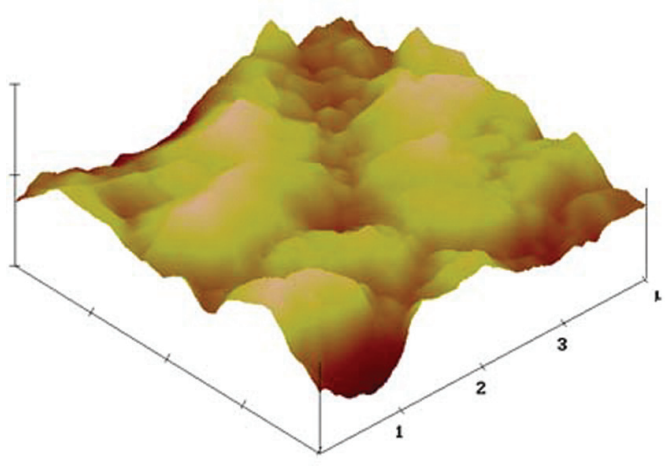

a)

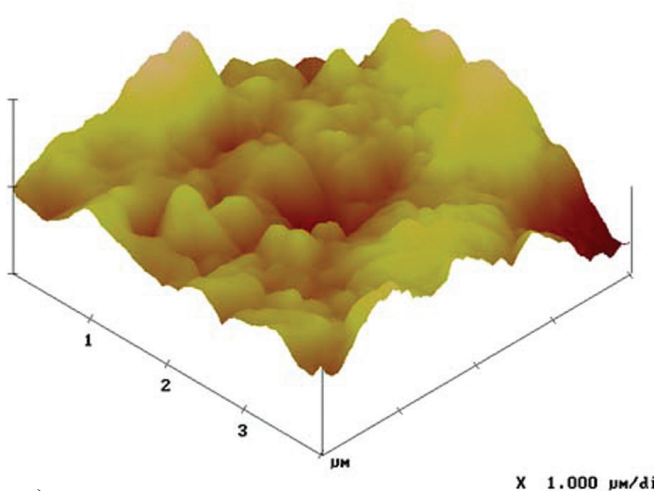

c)

$\begin{array}{ll}X & 1.000 \mu \mathrm{m} / \mathrm{diu} \\ 2 & 499.999 \\ \mathrm{~nm} / \mathrm{di}\end{array}$

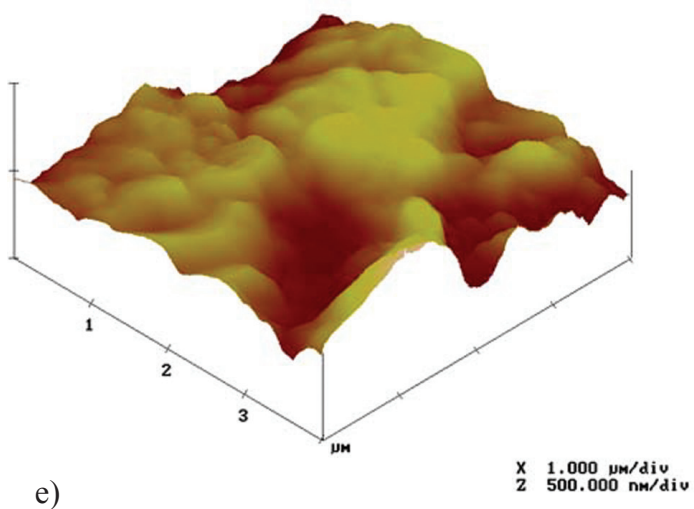

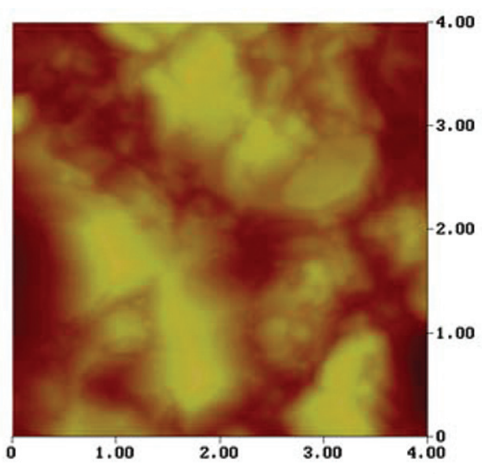

b)
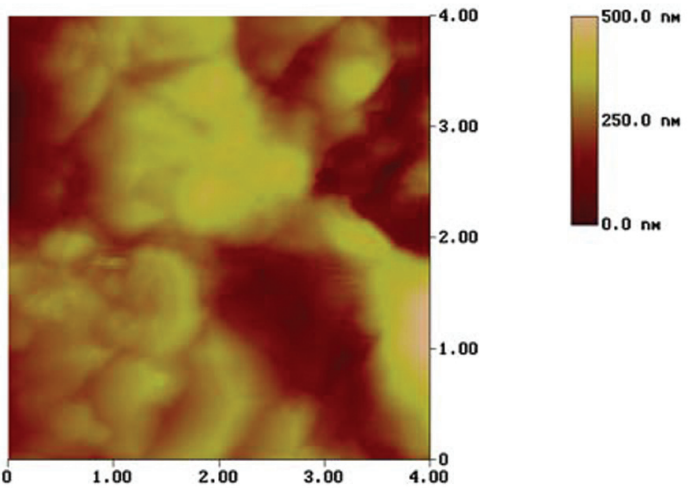

d)

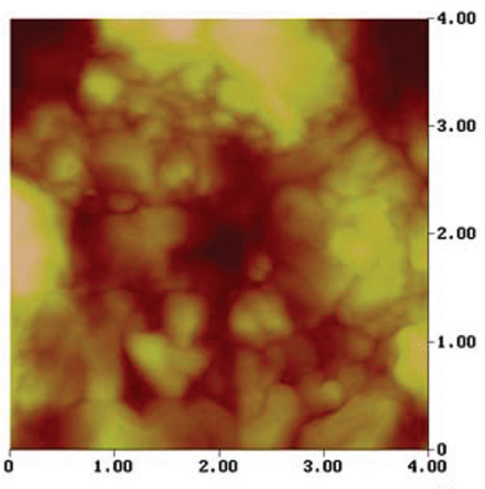

f)

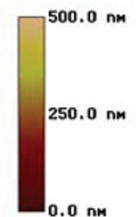

Fig. 21. 3D AFM images $(4 \times 4) \mu m^{2}(a, c, e)$ and $2 D$ AFM images $(4 \times 4) \mu m^{2}(b, d, f-$ top view $)$ of copper coatings deposited without brightener, of thickness: a, b): $15 \mu \mathrm{m}$; c, d): $30 \mu \mathrm{m}$, and e, f): $50 \mu \mathrm{m}$. Roughness of the sections: a, b): $75.31 \mathrm{~nm}$; c, d): $88.29 \mathrm{~nm}$, and e, f): $103.84 \mathrm{~nm}$.

Figures 19 and 20 show reflection vs. visible light wavelength curves. It can be noticed that in both cases diffuse reflection of these coatings are approximately the same value, or 0 $\%$. On the other hand, the degree of specular re- flection of the coatings deposited with the brightener approaches to total reflection and it increases with increase in coating thickness, yielding ideal reflectance of copper for wavelengths above $590 \mathrm{~nm}$. 


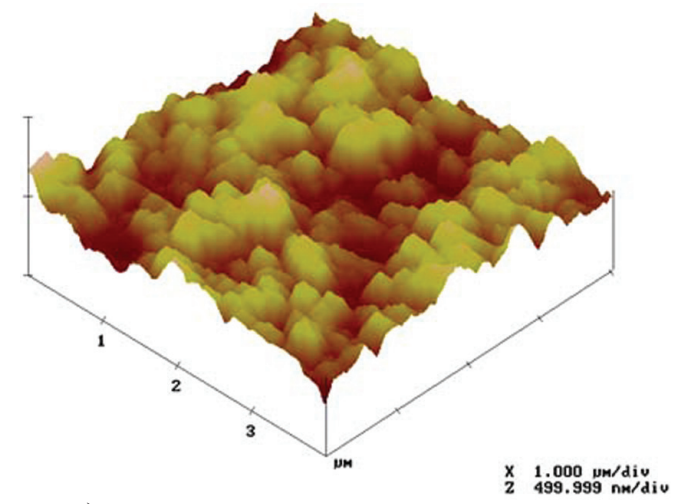

a)

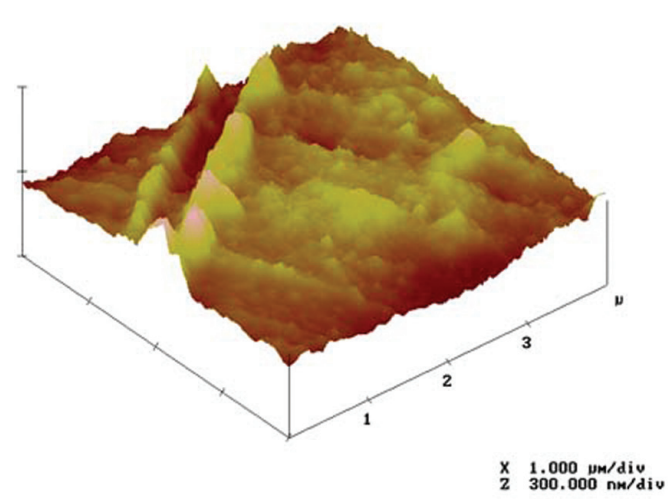

c)

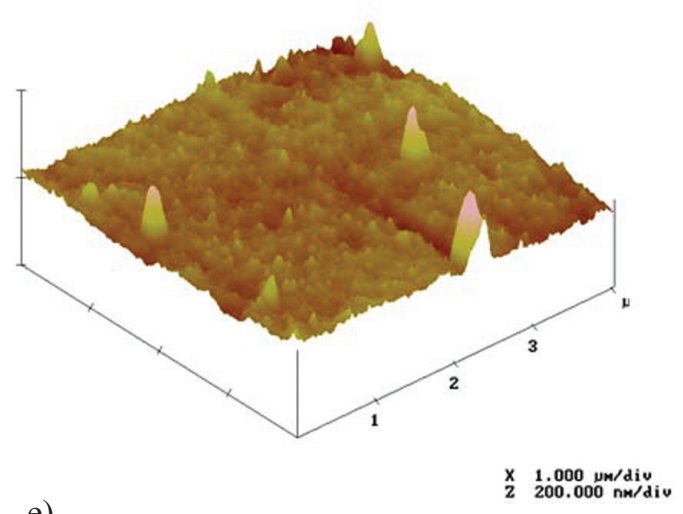

e)

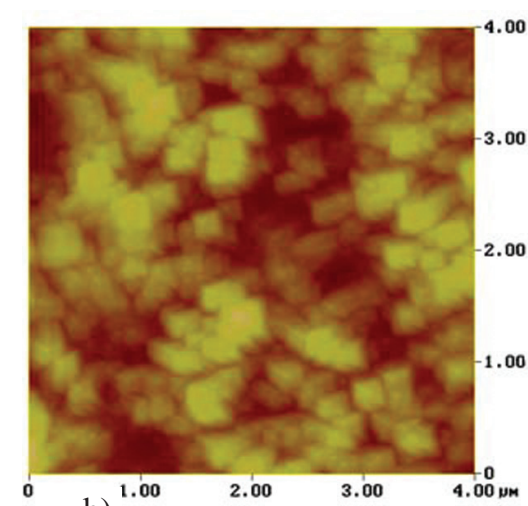

b)

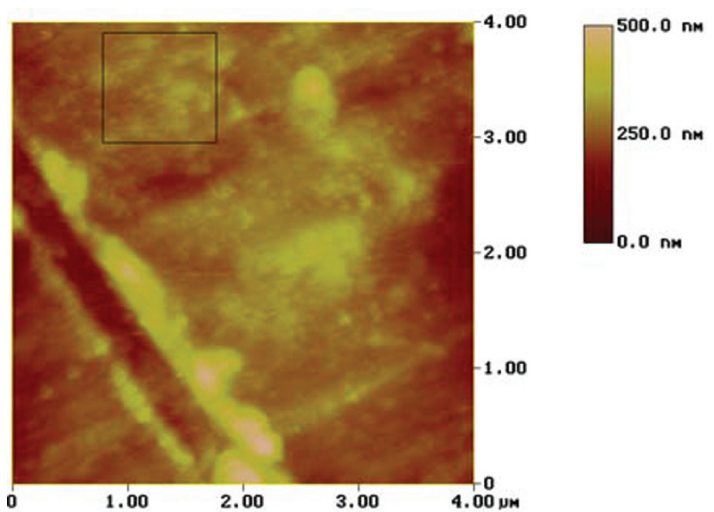

d)

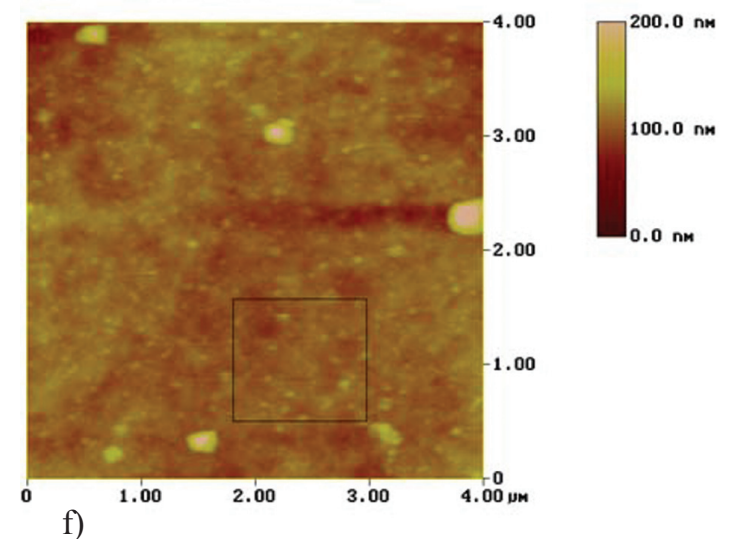

Figure 22. 3D AFM images $(4 \times 4) \mu \mathrm{m}^{2}(\mathrm{a}, \mathrm{c}, \mathrm{e})$ and $2 \mathrm{D}$ AFM images $(4 \times 4) \mu \mathrm{m}^{2}(\mathrm{~b}, \mathrm{~d}$, f - top view) of copper coatings deposited with the brightener, of thickness: a,b) $15 \mu \mathrm{m}, \mathrm{c}, \mathrm{d}) 30 \mu \mathrm{m}$ and e,f) $50 \mu \mathrm{m}$. Roughness of the sections: a,b) $62.63 \mathrm{~nm}, \mathrm{c}, \mathrm{d}) 34.28$ (12.53 nm selected part) and e,f) $12.18 \mathrm{~nm}$ (selected part of $6.68 \mathrm{~nm}$ ).

Corresponding AFM and STM images of copper coatings of different thickness, electrodeposited with and without brightener, as their section analysis, are shown from Figures 21-24.

It is evident from Figure 21 that there is noticeable upward trend in surface roughness with increase of deposition time, i.e. with the increase of coating thickness an increase of roughness occurs, which is consistent with the literature data $[21,22]$. 


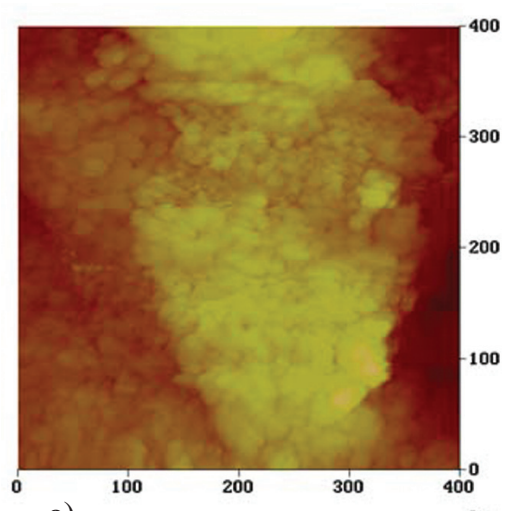

a)

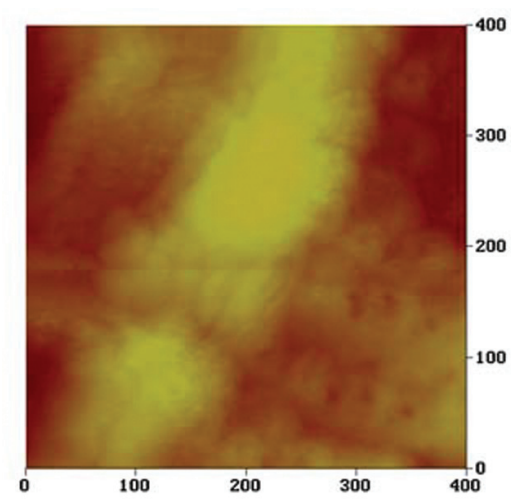

c)

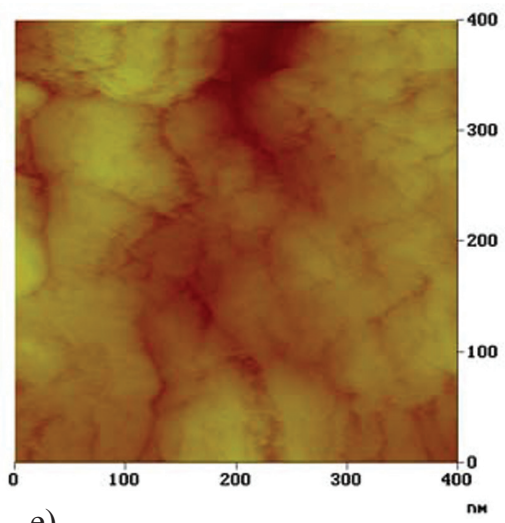

e)
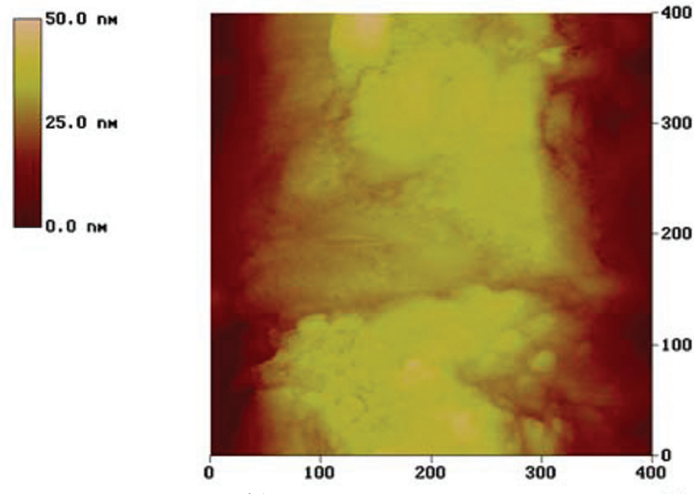

b)
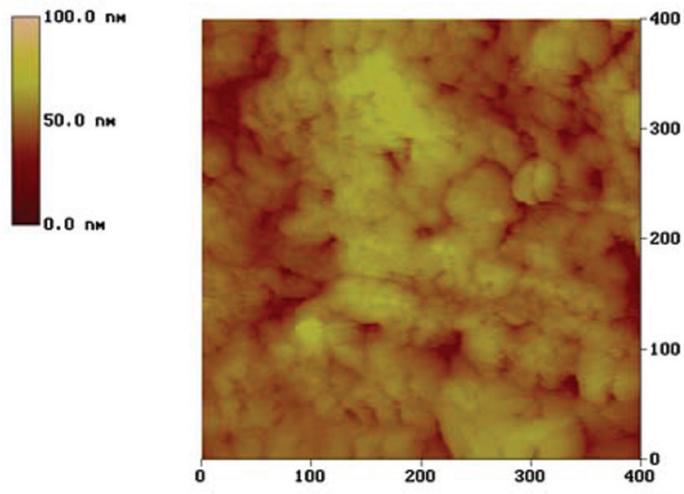

d)
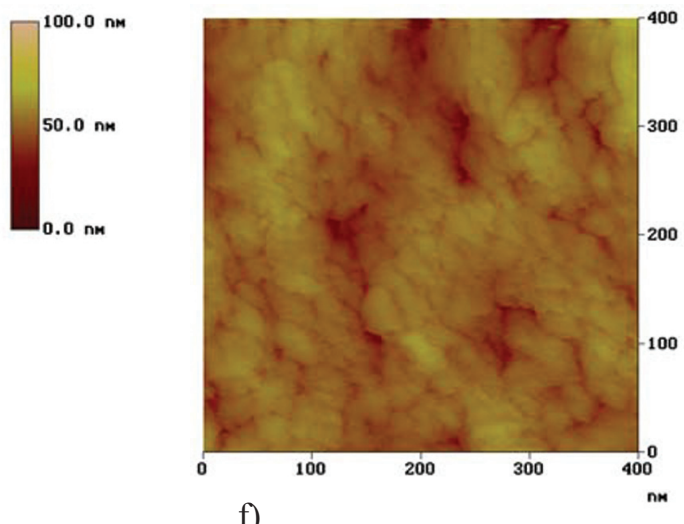

f)
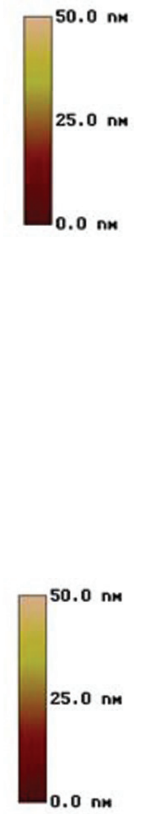

Figure 23. 2D STM images $(400 \times 400) \mathrm{nm}^{2}$ of copper coatings deposited without brightener $(\mathrm{a}, \mathrm{c}, \mathrm{e})$ and with the brightener (b, d, f) of thickness: a,b) $15 \mu \mathrm{m}, \mathrm{c}, \mathrm{d}) 30 \mu \mathrm{m}$ e, f) $50 \mu \mathrm{m}$. Roughness of the sections: a) $6.76 \mathrm{~nm}$, c) $8.31 \mathrm{~nm}$, e) $11.87 \mathrm{~nm}$, b) $11.09 \mathrm{~nm}$, d) $4.23 \mathrm{~nm} \mathrm{f)} 2.97 \mathrm{~nm}$.

From Figure 24 it is evident that with the brightener (levelers) it practically comes to a complete reduction of the amplitude of roughness (from several hundred nm to a few $\mathrm{nm}$ ), leading to the specular brightness.

\section{CONCLUSIONS}

Following the change in the relationship of specular, total and diffuse reflection it can be concluded that there has been a significant 


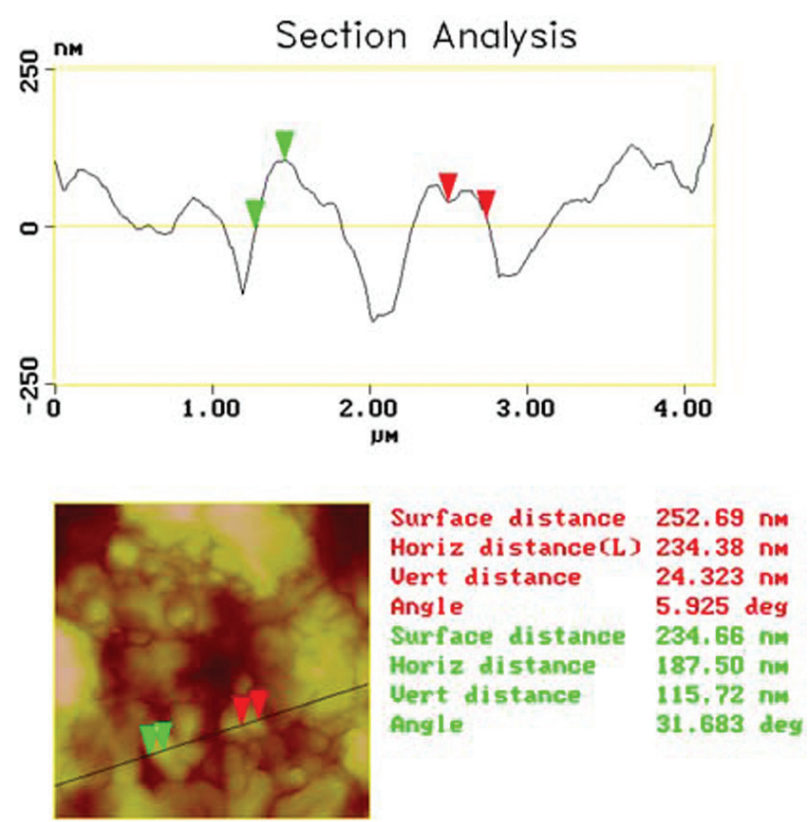

a)
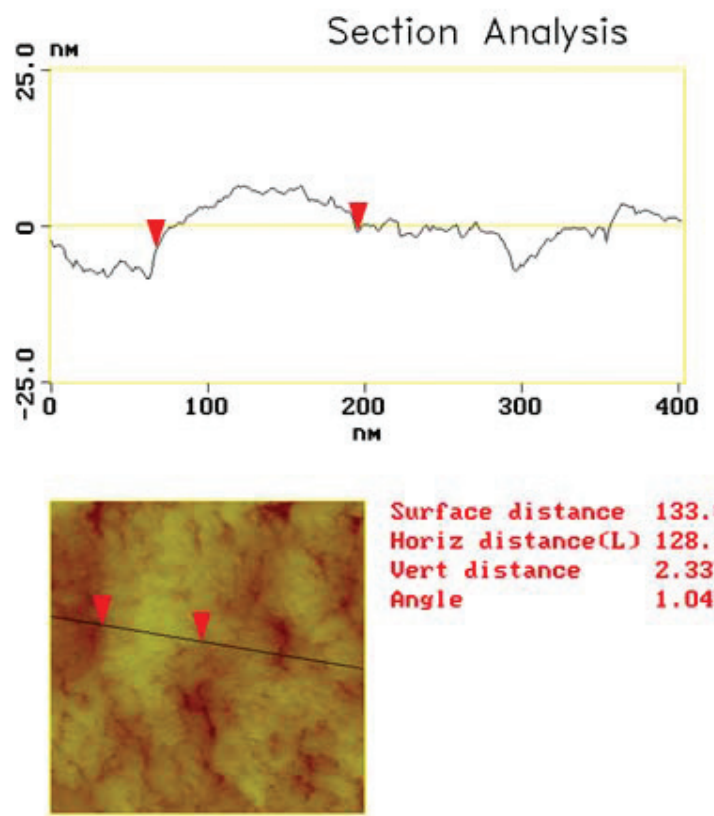

b)

Figure 24. 2D AFM linear analysis of the part of the copper coating surfaces, thickness of $50 \mu \mathrm{m}$ deposited a) without brightener, b) with the brightener.

increase in the surface brightness with samples polished electrochemically with respect to the initial surface. At the same time, increase in mirror reflection, thus increase in the brightness of the coating, becomes significant with increasing of coating thickness, i.e. with increasing deposition time in the presence of brightener, because the total reflection is brought close to the maximum. The sample with the greatest reflection has the thickest coating $(50 \mu \mathrm{m})$, which indicates that this pattern has the lowest roughness and fine-grain structure of the coating. To what extent the thickness of the coating can be increased, with addition of brightener or leveler, without increasing the surface roughness of metal coatings will be answered in next investigations.

Increase in brightness of electrochemically polished surface compared to mechanically polished surface is between $20-25 \%$. For the light wavelengths above $590 \mathrm{~nm}$, mirror reflection for all copper samples (except for samples with mat copper coatings), has a sudden jump and takes a constant value. Mechanically and electrochemically polished copper sam- ples have the value for mirror reflection of 90 $\%$, while the reflection for solely mechanically polished samples was 10-30\%.

Studying the roughness of the copper samples on submicron level, it was concluded that roughness amplitudes (about $2 \mathrm{~nm}$ ) have lower values than the shortest wavelength of visible light $(0.4 \mu \mathrm{m})$. It is obvious that high mirror brightness is not caused only by the roughness amplitude. The conclusion that follows from the observation of surface topography is that the cause of high mirror brightness is in large proportion of small flat and mutually parallel parts of the surface which are smooth at the atomic level. Increase in the degree of structure organization of the metal coatings leads to increase in the degree of mirror reflection.

Acknowledgement. The work was supported by the Ministry of Science and Technological Development of the Republic of Serbia under the research project: "Electrochemical synthesis and characterization of nanostructured functional materials for application in new technologies" (No. 172 046). 


\section{REFERENCES}

[1] Yu. Matulis, Blestyashchie Elektrliticheskie Pokrytiya, Mintis, Vilnius, 1969, 82.

[2] K. I. Popov, D. M. Škorić, M. G. Pavlović, B. M. Milošević, M. V. Stojanović, Upoređenje refleksije svetlosti sa mehanički i elektrohemijski glačanih metalnih površina, Zaštita materijala, 36 (1995), 119-124.

[3] S. I. Hotyanovich, Elektroosazhdenie Metallov Platinovoï gruppy, Mokslas, Vilnius, 1976

[4] F. A. Lowenheim, Electroplating, „McGraw-Hill Book Company“, New York, (1978), 146-152.

[5] C. Roth, H. Leidheiser, Electrodeposition from ionic liquids, J. Electrochem. Soc., 100 (1953), 553-565.

[6] N. D. Nikolić, E. R. Stojilković, D. R. Đurović, M. G. Pavlović, V. R. Knežević, The Preferred Orientation of Bright Copper Deposits, Mat. Sci. Forum, 352 (2000), 73-78.

[7] M. G. Pavlović, M. Gligorić, M. M. Pavlović, Lj. J. Pavlović, M. V. Tomić, N. D. Nikolić, Some questions about morphology and structure of electrodeposited metal coatings", $X X$ Congress of Chemists and Technologists of Macedonia, Abstract Book, Ohrid, Macedonia, CD, ECH-17-E (2008), 221.

[8] Yu. Matulis, Issledovaniya v oblasti electroosazhdeniya metallov, 28th ISE Meeting, Druzhba-Varna, Bulgaria, 1 (1977), 240.

[9] M. G. Pavlović, V. Radmilović, A. Dekanski, E. R. Stojilković, K. I. Popov, O hrapavosti sjajnih galvanskih prevlaka bakra, Zaštita materijala, 34 (1993), 7-13.

[10] K. I. Popov, M. G. Pavlović, Z. Rakočević, D. M. Škorić, The structure of bright copper surfaces, $J$. Serb. Chem. Soc., 60 (1995), 873-878.

[11] N. D. Nikolić, K. I. Popov, Z. Rakočević, D. R. Đurović, M. G. Pavlović, M. Stojanović, The structure of bright zinc coatings, J. Serb. Chem. Soc., 65 (2000), 819-827.
[12] J. D. Thomas, The transition from microthrowing power to macrothrowing power in electrodeposition from a cyanide copper bath, Proc. Am. Electroplaters Soc., 43 (1956), 60-67.

[13] O. Kardos, D. G. Foulke, Advances in Electrochemistry and Electrochemical Engineering, Vol. II /Ed. by C.W. Tobias), Interscience Publ., N. York, 1966, 145.

[14] A. R. Despić, K. I. Popov, Transport-Controlled Deposition and Dissolution of Metals, Monograpf in Modern Aspects of Electrochemistry, Plenum Press, N. York, 7 (1972), 199-313.

[15] L. Oniciu, L. Muresan, Some fundamental aspects of levelling and brightening in metal electrodeposition, J. Appl. Electrochem., 21 (1991), 565-574.

[16] S. Đorđević, M. Maksimović, M. G. Pavlović, K. I. Popov, Galvanotehnika, (Eds. M. Maksimović, D. Mrđenović), Tehnička knjiga, Beograd, 1998, 80-82.

[17] K. I. Popov, S. S. Đokić, B. N. Grgur, Fundamental Aspects of Electrometallurgy, Kluwer Academic / Plenum Publishers, New York, 2002.

[18] R. J. Nichols, D. Schröer, H. Meyer, Application of SPM in the metal plating industry, Scanning, 15 (1993), 266-273.

[19] W. Haiss, D. Lackey, J. K. Sass, H. Meyer, R. J. Nichols, A determination of copper overlayer structures on $\mathrm{Au}(111)$ in the presence of electrolyte additives, Chem. Phys. Letters, 200 (1992), 343-349.

[20] S. Grilikhes, Elektrokhimicheskoe i khimicheskoe polirovanie, Leningrad, Mashinostroenie, 1987, 53.

[21] K. I. Popov, M. G. Pavlović, Lj. J. Pavlović, M. I. Čekerevac, G. Ž. Remović, Electrode surface coarsening in pulsating overpotential copper electrodeposition, Surf. Coat. Technol., 34 (1988), 355-363.

[22] K. I. Popov, Lj. J. Pavlović, M. G. Pavlović, M. I. Čekerevac, Electrode surface coarsening in potentiostatic copper electrodeposition, Surf. Coat. Technol., 35 (1988), 39-45. 